\begin{tabular}{|c|c|}
\hline 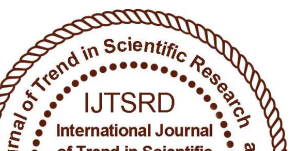 & $\begin{array}{l}\text { International Journal of Trend in Scientific } \\
\text { Research and Development (IJTSRD) }\end{array}$ \\
\hline $\begin{array}{lll} & \\
0\end{array}$ & International Open Access Journal \\
\hline 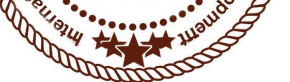 & ISSN No: 2456 - 6470 | www.ijtsrd.com | Volume - 2 | Issue -5 \\
\hline
\end{tabular}

\title{
Safe Patient Care: Knowledge, Attitude and Practice Among ICU Nurses
}

\author{
Lillykutty M. $\mathbf{J}^{1}$, Josy A Mathew ${ }^{2}$, Dhanya Jose ${ }^{3}$ \\ ${ }^{1}$ Principal, ${ }^{2}$ Professor, ${ }^{3}$ Assistant Professor \\ Lourdes College of Nursing Ernakulam, Ernakulam, Kerala, India
}

\begin{abstract}
The present study describes nurses' knowledge, attitude and self-reported practice regarding safe patient care. A quantitative descriptive correlational design study, using purposive sampling technique was conducted on 70 ICU nurses. The overall result indicates that majority of the sample has good knowledge $(93 \%)$ and positive attitude $(87 \%)$ towards safe patient care. All sample (100\%) reported good patient safety practices. The findings of the study also show no association between knowledge with educational status and years of experience $\left(\chi^{2}=0.021\right.$, $0.86)$ at 0.05 level of significance. The association between attitude with educational status and year of experience $\left(\chi^{2}=152.56,80.2\right)$ are statistically significant at .05 level. While there is a correlation exists between knowledge and practice $(\mathrm{r}=0.361$, $\mathrm{p}=0.002$ ) at 0.05 level of significance, the correlation between knowledge and attitude $(\mathrm{r}=0.208, \mathrm{p}=0.084)$, practice and attitude $(\mathrm{r}=0.032, \mathrm{p}=0.795)$ are not significant at 0.05 level.
\end{abstract}

Keywords: knowledge, attitude, practice, safe patient care, ICU nurses

\section{INTRODUCTION}

Today, nursing has become an exciting profession in the world. Trained nurses embodied in compassion are the greatest blessings to humanity. Nurses are exceptional; they have a responsibility to support safe patient care. Their role involves a balanced mixture of their knowledge, attitude and practice.

\section{BACKGROUND OF THE STUDY}

Qualified nursing professionals across the globe have a fascinating interest towards safe patient care. ${ }^{1}$ Safe patient care and the efforts to define its quality began with Florence Nightingale in the 1850 s, when she used statistical methods to identify the relationship between patient outcomes and environmental conditions. $^{2}$ This noble history on outcome measurements attracted the respect and warm approval from statisticians and epidemiologists alike. ${ }^{3}$ Nightingale style and innovative thinking are indispensable in modern nursing, as both strive to provide safe patient care. ${ }^{4}$

\section{SIGNIFICANCE OF THE STUDY}

The principle of safe patient care resides 'in the prevention of harm to patients'. Moreover, it is the prevention of errors among health care professionals and subsequent adverse events among patients in hospitals. ${ }^{5}$ According to the updates on patient safety by WHO (2018), there is 1 in 300 chance of a patient being harmed during health care, 421 million hospitalizations in world annually and approximately 42.7 million adverse events occur in patients during these hospitalizations ${ }^{6}$ Patient safety has become increasingly imperative to hospitals. Nurses are the driving force behind patient perceptions of safety and it also is a concern among nursing professionals.

\section{PURPOSE OF THE STUDY}

The overall purpose of this study was to explore the knowledge, attitude and practice of ICU nurses 
regarding safe patient care and to explain their relationships, and their association with the year of experience and educational status of the sample.

\section{STATEMENT OF THE PROBLEM}

A study to assess the knowledge, attitude and practice of safe patient care among ICU nurses in a selected hospital, Ernakulam.

\section{OBJECTIVES}

1. To assess the knowledge regarding safe patient care among ICU nurses.

2. To assess the attitude regarding safe patient care among ICU nurses.

3. To assess the practice regarding safe patient care among ICU nurses.

4. To find the association between the study variables and selected demographic variables

5. To determine the correlation between the study variables

\section{ASSUMPTIONS OF THE STUDY}

The study assumes that medical ICU nurses may have knowledge, positive attitude and adequate patient safety practices. The knowledge, attitude and practice regarding safe patient care may vary among medical ICU nurses.

\section{RESEARCH HYPOTHESES}

The following hypotheses were tested at 0.05 level of significance.

$\mathrm{H}_{1}$ : There will be correlation between knowledge and attitude regarding safe patient care.

$\mathrm{H}_{2}$ : There will be correlation between attitude and practice regarding safe patient care.

$\mathrm{H}_{3}$ : There will be correlation between knowledge and practice regarding safe patient care.

$\mathrm{H}_{4}$ : There will be an association between knowledge, attitude and practice with selected demographic variables of the sample.

\section{DELIMITATIONS}

The study is delimited to single setting, medical ICUs, self reported scores of practice and staff nurses.

\section{REVIEW OF LITERATURE}

The result of a cross sectional comparative study (Attia Bari et al. 2017) on knowledge of patient safety among 150 PG residents and 150 nurses in a tertiary care hospital showed a high level of positive perception with higher mean score among nurses compared to PG residents $(p=0.004)^{8}$. Brasaite I, et al. (2014) conducted a study on attitude regarding patient safety in a sample of 1082 health care personnel, including physicians, nurses and nurse assistants from three hospitals in western Lithuania. The result showed a positive attitude among the sample with regard to patient safety practices ${ }^{9}$. A descriptive survey by K. Lalrindiki et al. (2013) on the knowledge and practice regarding safe patient care among 50 staff nurses revealed that $58 \%$ of subjects were with average knowledge, and 56\% had average practice; there was a positive correlation $(\mathrm{r}=0.558)$ between knowledge and practice ${ }^{10}$.

\section{RESEARCH METHODOLOGY}

$>$ Research approach: Quantitative

$>$ Research design: Correlational descriptive survey $^{11}$

Setting: selected hospital in Ernakulam

Study variables: Knowledge, attitude and practice regarding safe patient care

Sample: staff nurses from Medical ICUs

Sampling technique: Purposive sampling

Sampling process: The sample for this study was recruited using non-probability purposive sampling technique. They were staff nurses in medical ICUs during data collection period. Head nurses, shift incharges and supervisors were excluded from the data collection.

\section{Tools and techniques}

A. Tool -1, the section A consists of demographic variables which includes educational status and years of experience. Section B includes Structured Knowledge Questionnaire (20 items) developed based on International Patient Safety Goals $\left(\right.$ IPSG) ${ }^{12}$.The knowledge scores are: 1-6 'poor knowledge', 7-13 'average knowledge', 14-20 'good knowledge'.

B. Tool -2, is a Safety Attitude Questionnaire (30 items) measured the mind-set of ICU nurses regarding safe patient care. It is a 5-point scale attitude to safe patient care. The attitude scores are: 30 - 70 'negative attitude', 71-110 'neutral attitude', 111-150 'positive attitude'.

C. Tool - 3, is Safety Practice Check Lists (20 items) based on IPSG, measured self-reported patient 
International Journal of Trend in Scientific Research and Development (IJTSRD) ISSN: 2456-6470

care safety practices ${ }^{12}$. The practice scores are: 1-6 'poor practice', 7-13 'average practice', and 14-20 'good practice'.

\section{DATA ANALYSIS}

Table 1: Distribution of sample based on years of experience and educational status

\begin{tabular}{|c|c|c|c|}
\hline \multirow{2}{*}{$\begin{array}{c}\text { Sample } \\
\text { variables }\end{array}$} & $\begin{array}{c}\text { Classificatio } \\
\text { n }\end{array}$ & $\begin{array}{c}\text { Frequenc } \\
\mathbf{y}(\mathbf{f})\end{array}$ & $\begin{array}{c}\text { Percentag } \\
\text { e }(\%)\end{array}$ \\
\hline $\begin{array}{c}\text { Years of } \\
\text { experience }\end{array}$ & $1-4$ & 35 & 50 \\
\cline { 2 - 4 } & $4-8$ & 32 & 45.7 \\
\cline { 2 - 4 } & $8-12$ & 3 & 4.3 \\
\hline \multirow{2}{*}{$\begin{array}{c}\text { Education } \\
\text { al status }\end{array}$} & BSc Nursing & 33 & 47.2 \\
\cline { 2 - 4 } & $\begin{array}{c}\text { GNM } \\
\text { Nursing }\end{array}$ & 37 & 52.8 \\
\hline
\end{tabular}

Table 1 show that $50 \%$ have $1-4$ years of experience, another $45.7 \%$ with $4-8$ years and the rest $4.3 \%$ with 8-12 years. Regarding the educational status $47.2 \%$ are B.Sc. nurses and $52.8 \%$ are GNM nurses.
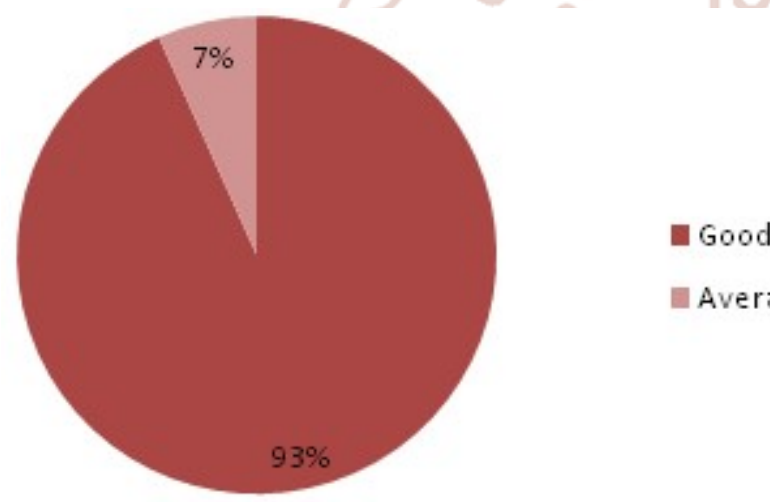

Average

Figure 1: Knowledge scores on safe patient care
Figure 1 shows that majority of the sample 65 (93\%) are having good knowledge whereas $5(7 \%)$ are having average knowledge regarding safe patient care.

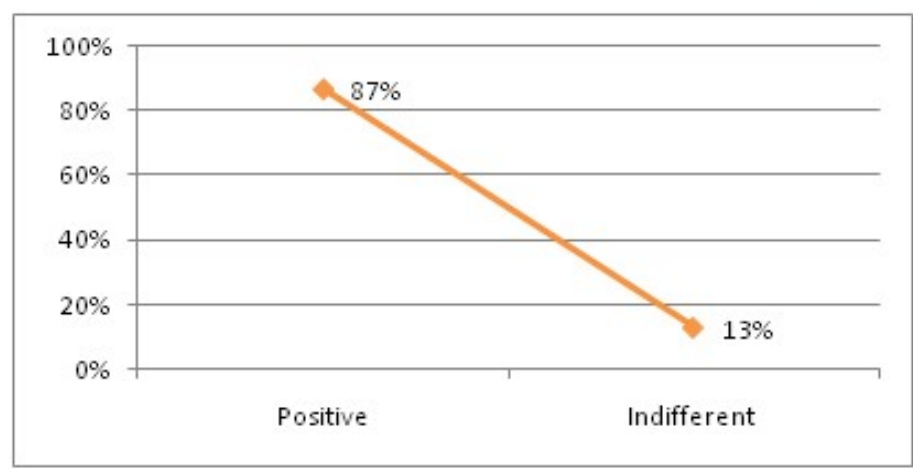

Figure 2: Attitude towards safe patient care

Figure 2 shows that majority $61(87 \%)$ of the sample are having positive attitude and $9(13 \%)$ having neutral attitude towards safe patient care.

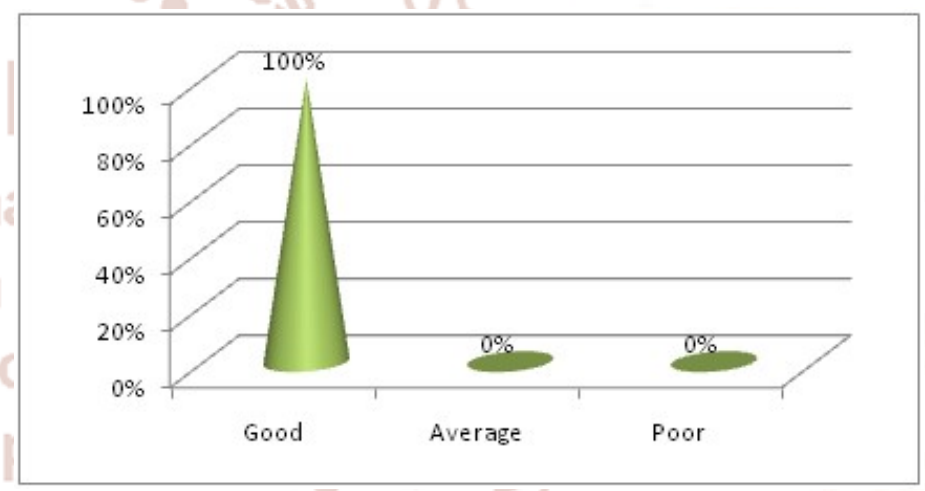

Figure 3: Practice of safe patient care.

Figure 3 shows that the entire sample $(100 \%)$ has good practice regarding safe patient care.

Table 2: Association between knowledge and selected demographic variables

\begin{tabular}{|c|c|c|c|c|c|c|c|c|}
\hline \multirow[b]{3}{*}{ Variables } & \multirow[b]{3}{*}{ Category } & \multicolumn{4}{|c|}{ Knowledge } & \multirow[b]{3}{*}{ df } & \multirow[b]{3}{*}{$x^{2}$} & \multirow[b]{3}{*}{ Tabulated value } \\
\hline & & \multicolumn{2}{|c|}{ Average } & \multicolumn{2}{|c|}{ Good } & & & \\
\hline & & f & $\%$ & f & $\%$ & & & \\
\hline \multirow[t]{2}{*}{ Educational status ${ }^{\#}$} & GNM & 2 & 2.9 & 35 & 50 & \multirow[t]{2}{*}{1} & \multirow[t]{2}{*}{$0.021^{\mathrm{ns}}$} & \multirow[t]{2}{*}{3.84} \\
\hline & B.Sc & 3 & 4.3 & 30 & 42.8 & & & \\
\hline \multirow[t]{2}{*}{ Years of experience $^{\#}$} & $1-4$ & 4 & 5.7 & 31 & 44.3 & \multirow[b]{2}{*}{1} & \multirow[b]{2}{*}{$0.86^{\mathrm{ns}}$} & \multirow[b]{2}{*}{3.84} \\
\hline & $>4$ & 1 & 1.4 & 34 & 48.6 & & & \\
\hline
\end{tabular}

ns: not significant at 0.05 level; \# Yates correction done

Table 2 shows association between knowledge with educational status and years of experience. The obtained $\chi^{2}$ values $\left(\chi^{2}=0.021,0.86\right)$ are not statistically significant at 0.05 level. Hence the null hypothesis is accepted, showing no significant association between knowledge with educational status and years of experience. 
International Journal of Trend in Scientific Research and Development (IJTSRD) ISSN: 2456-6470

Table 3: Association between attitude and selected demographic variables

\begin{tabular}{|c|c|c|c|c|c|c|c|c|}
\hline \multirow{3}{*}{ Variables } & \multirow{3}{*}{ Category } & \multicolumn{4}{|c|}{ Attitude } & \multirow{3}{*}{ df } & \multirow{3}{*}{$\chi^{2}$} & \multirow{3}{*}{ Tabulated value } \\
\hline & & \multicolumn{2}{|c|}{ Neutral } & \multicolumn{2}{|c|}{ Positive } & & & \\
\hline & & $\mathrm{f}$ & $\%$ & $f$ & $\%$ & & & \\
\hline \multirow[t]{2}{*}{ Educational status ${ }^{\#}$} & GNM & 6 & 8.6 & 31 & 44.3 & \multirow[b]{2}{*}{1} & \multirow[b]{2}{*}{$152.56^{*}$} & \multirow[b]{2}{*}{3.84} \\
\hline & B.Sc. & 3 & 4.3 & 30 & 42.8 & & & \\
\hline \multirow[t]{2}{*}{ Years of experience $^{\#}$} & $1-4$ & 3 & 4.3 & 32 & 45.7 & \multirow[t]{2}{*}{1} & \multirow[t]{2}{*}{$80.2^{*}$} & \multirow[t]{2}{*}{3.84} \\
\hline & $>4$ & 6 & 8.6 & 29 & 41.4 & & & \\
\hline
\end{tabular}

Table 3 shows association between attitude with educational status and years of experience. The obtained value $\left(\chi^{2}=152.56,80.2\right)$ is statistically significant at 0.05 level. Hence the null hypothesis is rejected and research hypothesis is accepted, showing significant association between knowledge with educational status and years of experience.

\section{Table 4: Correlation between study variables}

\begin{tabular}{|c|c|c|}
\hline Variables & $\begin{array}{c}\text { Pearson's } \\
\text { Correlation }(\mathrm{r})\end{array}$ & p value \\
\hline $\begin{array}{c}\text { Knowledge and } \\
\text { attitude }\end{array}$ & 0.208 & $0.084^{\mathrm{ns}}$ \\
\hline $\begin{array}{c}\text { Attitude and } \\
\text { practice }\end{array}$ & 0.032 & $0.795^{\mathrm{ns}}$ \\
\hline $\begin{array}{c}\text { Knowledge and } \\
\text { practice }\end{array}$ & 0.361 & Of $^{2} 0.002^{* *}$ \\
\hline \multicolumn{2}{|c|}{$* *$ Significant at 0.05 level } \\
\hline
\end{tabular}

Table 4 depicts no correlation between knowledge and attitude $(\mathrm{r}=0.208, \mathrm{p}=0.084)$, practice and attitude $(\mathrm{r}=0.032, \mathrm{p}=0.795)$ regarding safe patient care. The correlation between knowledge and practice $(\mathrm{r}=0.361$, $\mathrm{p}=0.002)$ is statistically significant at 0.05 level.

\section{RESULTS}

With regard to the years of experience, $50 \%$ of the sample has $1-4$ years, $45.7 \%$ have $4-8$ years and $4.3 \%$ have 8-12 years of experience. Among the sample, $47.2 \%$ are B.Sc. nurses and $52.8 \%$ are GNM nurses. Majority of the sample has good knowledge (65, $93 \%)$ and positive attitude $(61,87 \%)$ towards safe patient care. All sample $(70,100 \%)$ reported good patient safety practices. The findings of the study also show no significant association between knowledge with educational status and years of experience. The obtained $\chi^{2}$ values $\left(\chi^{2}=0.021,0.86\right)$ are not statistically significant at 0.05 level. The association between attitude with educational status and year of experience $\left(\chi^{2}=152.56,80.2\right)$ are statistically significant at .05 level. While there is a correlation exists between knowledge and practice $(\mathrm{r}=0.361$, $\mathrm{p}=0.002$ ) at 0.05 level of significance, no correlation is found between knowledge and attitude $(\mathrm{r}=0.208$, $\mathrm{p}=0.084)$, practice and attitude $(\mathrm{r}=0.032, \mathrm{p}=0.795)$ regarding safe patient care.

\section{DISCUSSION}

A large part of the patient care is the effort of nurses. Nurses apply their knowledge, skills and experience to care for the various and changing needs of patients $^{13}$. The quality of care by nurse correspond with outcome measures of quality in a hospital ${ }^{14}$. The present study also illustrates that nurses have a good knowledge and practice regarding safe patient care are and their attitude is positive towards safe patient are. This findings contradict the findings of a study ${ }^{9}$ that indicated a quite a low level of safety knowledge among health care professionals. The findings of an another $\operatorname{study}^{15}$ that investigated the level of knowledge, attitudes, and practices of nurses about preventing the spread and management of HAIs at University Clinical Center of Kosovo (UCCK) support the present study. The general level of knowledge of nurses about the spread of HAIs was $90 \%$, about the attitudes was $84.4 \%$ and about the nurses' practices was $76.2 \%$.

\section{IMPLICATIONS OF THE STUDY}

Nursing Practice: Advanced basis such as guidelines and protocols help to adhere to safe patient care by nurses. Nurses must continue to identify knowledge; attitude and practice gap as well. They must sustain their proficiency through training and in service education.

Nursing Education: Nursing students must be provided with opportunities to participate in patient 
safety practices through effective clinical instructions and training. Nursing clinical should be conducted emphasizing safe patient care.

Nursing Administration: Nurse Administrators should round on patients time to time to ensure safe patient care, using evidence based findings and make available clinical guidelines and protocols for the new nurses and nursing students.

Nursing Research: Nurse Researchers can conduct interventional studies regarding safe patient care. They can also conduct studies on factors contributing to safe patient care.

\section{CONCLUSION}

The present study claims that Medical ICU nurses have good knowledge, attitude and practice regarding safe patient care. Their knowledge and practice have a positive correlation. The study concludes that good knowledge, attitude and practice enhance safe patient care. Nurses are the driving force behind patient perceptions of safety and satisfaction.

\section{REFERENCES}

1. Andreas Charalambous, Rena Papdopoulus, Alan Beadsmoore .Quality Nursing Care: Review of the literature on patients' and nurses' interpretations: Hellenic Journal ev of NursingScience.2009. Available at $\mathrm{http}: / / \mathrm{www} \cdot$ researchgate.net.

2. Montalvo. The National Database of Nursing Quality Indicators (NDNQI): Online Journal Issues Nurse. (2007); 12.

3. Griffiths P, Jull A. How good is the evidence for using risk assessment to prevent pressure ulcers: Nursing Times. 2010; 106 (14): 10-13.

4. Hendrich et al. maximizing the impact of nursing care quality: Health care leadership. September 2008. Available at: https://www.brikbase.org.

5. Institute of Medicine. Keeping patients safe: transforming the work environment of nurses. Washington, DC: National Academy Press. 2004.

6. Ten facts on patient safety (WHO, 2018). Google search, available at www.who.int.

7. Brakley D, Kroth M, \& Gregson J. The impact of nurse rounding on patient satisfaction in a medical-surgical hospital unit: Medsurg Nursing. 2011; 20(6): 327-32

8. Attia Bari et al (2017). Patient safety awareness among postgraduate students and nurses in a tertiary health care facility. Pakistan Journal of Medical Sciences 33 (5) 1059 -1064.

9. I Brasaite et al. (2016). Health care professional's attitude regarding patient safety: cross sectional survey. BMC Research notes 9:177.

10. 10. K. Lalrindiki etal. (2013). Knowledge and Practices regarding Advanced Patient Care among Staff Nurses Working in a Tertiary Care Hospital. International Journal of Science and Research (IJSR) ISSN (Online): 2319-7064.

11. Polit F Denise. Nursing research. Principles and methods. $6^{\text {th }}$ edn. Washington: Lippincott publication; 1999.

12. International Patient Safety Goals. Google search, available at: www.//joint commissioninternational.org.

13. Ronda G. Hughes. Nurses at the "sharp end" of patient care. Google search, available at: https://www.ncbi.nlm.nih.gov

14. Blignaut et al. (2013). Nurse qualifications and perceptions of patient safety and quality of care in South Africa. Nursing and Health sciences. Volume 16 (2), pages 224-2314.

15. Abdullah Gruda and Idriz Sopjani (2017). The knowledge, attitudes and Practices of Nurses toward Management of Hospital-Acquired Infections in the University Clinical Center of Kosovo. Mater Sociomed. Jun; 29 (2): 84-87. 